\title{
Western-trained music therapist in China: set up a music therapy program in Chinese medical setting
}

\section{在西方受训的音乐治疗师 : 建立符合中国医疗体系的 音乐治疗项目}

\author{
Qian Li 李茜 \\ Wuxi Mental Health Center, China
}

\begin{abstract}
This article provides an overview of the history and development of music therapy in China medical setting. It also includes a pilot project, set up by a western-trained music therapist in a Chinese psychiatric hospital in 2013. The project aimed to explore how to apply music therapy based on Chinese-culture needs, educate and inform participants (medical staff/patients/families) on issues and potentials to mental patients; explain common misunderstandings by using contemporary music therapy perspectives and engage patients in different music therapy models to improve their functions. The project has been ongoing for 4 years and has some good outcomes. The challenges arising from the integration of Chinese and Western cultures are also included in this article.
\end{abstract}

Keywords: Music Therapy program, Psychiatric Hospital, Cross-culture, Adult Mental Disorders, Challenges and outcomes

\section{摘要}

本文介绍了音乐治疗在中国医疗领域中的历史和发展现状。2013年一位西方受训的音 乐治疗师加入到中国无锡的精神病医院，开始在该领域尝试建立出符合中国国情的医疗 音乐治疗项目。该项目主要在探索如何建立起满足中国文化需要的音乐治疗; 如何将西 方的人本理念灌输到中国的精神病院; 如何用当代音乐治疗理念来解释过去遗留在中国 音乐治疗界的一些错误认知; 如何再创造的使用西方常用的音乐治疗技术来帮助中国的 病人达到康复的目的。该项目已持续有4年之久，获得了一些好的结果，项目仍然在持 续中。此外，进行中西方文化融合的过程中产生的种种挑战也将在本文中被讨论到。

\section{关键词: 音乐治疗项目，精神病医院，跨文化，成年精神病人，挑战与结果}

\section{The history and development of music therapy in Chinese medical setting}

Chinese contemporary music therapy has begun in the late 80 s of 20 century. Professon Ruibang Liu from music therapy program of the State University of Arizona, America was invited to give lecture in Music Therapy in Central Conservatory of Music in Beijing, China. This is the first time that music therapy has been systematically introduced as a 
profession, and has successfully captured the attention of many musicians and doctors. Professor Boyuan Zhang (1984) from Psychological School of the University of Beijing has published an experimental report A Study of the Mental and Physical Reaction from Music. The study has demonstrated the differences of physical reaction after listening to active and sedate music. This is the first published study on music therapy in China, followed with several articles on the clinical exploration of music therapy. (Tian Gao, 2007)

中国当代音乐治疗的出现是在 20 世纪 80 年代后期，美国亚利桑那州立大学 音乐治疗教授刘邦瑞在中央音乐学院进行关于音乐治疗学的讲学，这是第一次 对音乐治疗的系统科学的介绍，激发起很多音乐家和医生对音乐治疗的兴 趣。1984年北京大学心理学教授张博远发表了《音乐的身心反应研究》实验报 考，报告了被试在聆听欢乐的音乐和安静抒情的音乐时的不同生理反应。这是 中国第一次发表的音乐治疗科学研究报告，之后又陆续有人发表了多篇有关音 乐治疗在临床探索的报告(Tian Gao, 2007).

In clinical practice, music therapy was first introduced to patients by staff from Ma Wang Dui Nursing Home of Changsha. Since then, more than 200 hospitals have set up music therapy departments, and many medical team members and music lovers have started to explore the application of music therapy. In 1989, a group of psychiatrists and self-taught music therapists founded the Chinese Music Therapy Association. National conferences and seminars focusing on music therapy have been held every 2-3 years. Unfortunately, although most of the hospitals put a lot of efforts on exploring music therapy from 1989 to 1999 , many hospitals have decided to close the music therapy department in 1999 with the following reasons, which were: 1 , music therapy has been considered as musical prescription, as the music listening was the only way to employ for patients. For example, people with depression were suggested to listen to happy music, and people with mania was to listen to sedate music. Patients were unable to feel the empathy from therapists and music. 2, there was a lack of music therapy training in China (Tian Gao, 2007).

在临床的实际应用中，是湖南长沙马王堆疗养院首次对病人使用音乐，此后 不久，全国近200多家医院陆续建立音乐治疗室，大量医务工作者和部分音乐 爱好者投入到音乐治疗探索中。1989年中国音乐治疗学会成立。没2-3年举行一 次全国音乐治疗学术会议。然而，遗憾的是自1989年-1999年中，尽管众多医 院进行了音乐治疗方面的尝试，但到99年时，大量的医院关闭了音乐治疗室 (Tian Gao, 2007)。其原因有两方面 : 1、大部分医院只是采用简单的为病人播放 音乐的形式，甚至出现 “音乐处方” 的概念，例如抑郁的病人听一些开心的音 乐，躁狂的病人听一些安静的音乐等，长期以来，病人在音乐中没能获得基本 的共情，最后越来越多的病人对这种形式的治疗也失去了信心。2、缺少专业音 乐治疗师的培训。

\section{Education programs of music therapy in China}

Therefore, music therapy research center has been established in the central conservatory of music since 1996. Master of music therapy program has started since 1999, followed with a bachelor of music therapy program was established in 2003. The standards and goals of professional training were strictly according to the requirements of 
American Music Therapy Association. Music therapy as a profession has been established in China for two decades up to 2017, there are over 100 music therapists complete training. Professional music therapy programs are to continue expanding, to date, 13 universities have established the music therapy program in China.

于是，1996年中央音乐学院成立音乐治疗研究中心，1999年招收硕士研究 生，2003年开始招收本科生，该校的专业教学标准和培养目标严格按照美国音 乐治疗协会的要去标准开设所有课程，至2017年止该专业在中国成立20年，培 养出近百名音乐治疗师，一些音乐治疗师继续在中国的其他城市进行学科专业 的建立，因此至今为止，中国共有13所大学开设音乐治疗专业。

There are at least $1 / 3$ of music therapist graduates still active in this area. Most of them have been endeavoring in universities, special education organizations, and/or enterprises, and hardly working in health system. The reasons include: 1 , a lack of job title for music therapy practitioners within Chinese health system affect the talent introduction policies and career development; 2 , humanistic care concept has been neglected in Chinese health care for a long time.

毕业的专业音乐治疗师中有至少 $1 / 3$ 从事本职工作，大部分在高校，特教， 或者企业工作，鲜少进入到医疗系统。其原因包括 : 1 、卫生系统内管理制度与 非医学院音乐治疗专业的毕业生缺之相应技术职称衔接，影响了相关人才的引 进及业务发展。2、中国医疗卫生理念中，人文关怀的理念被长期忽视。

The situation has changed since rehabilitation was introduced to medical field. Rehabilitation, as a new branch discipline, is emphasized to improve functioning physically, psychologically and spiritually. The focuses is not just protect patients' life, but also to regain overall functioning, promote quality of life, return to society, and have a meaningful life. Rehabilitation concept has been introduced to China since 1983, and was officially part of the Medicare in 2011. This resulted in a great need of establishing rehabilitation departments as well as physicians' introduction in mainstream hospitals in China, which also opened a tunnel for integrating music therapists into medical field.

该现象自康复医学引入到医疗领域后开始出现了一些变化。康复医学做为医 学一个新分支学科，强调功能上的康复，强调使患者不但在身体上，而且在心 理和精神上得到康复。它的着眼点不仅在保存伤残者的生命，而且要尽量恢复 其功能，提高生活素质，重返社会，过有意义的生活。中国的康复概念自1983 年引入，直到2011年，康复正式进入医保，三甲医院被迫建立康复科，大量康 复人员急需，这也给音乐治疗师打开了一道进入医疗领域的通道。

\section{Music therapy in Wuxi Mental Health Center}

Psychiatric Rehabilitation Ward of Wuxi Mental Health Center (MHCW) was established in 2009. This was the first public hospital in Jiangsu Province owning a mental rehabilitation program, and has tried to introduce music therapy since 2010. A psychiatrist and two nurses have started the Music Therapy Program in Wuxi (MTPW), major using music listening and song singing. In 2013, evidence based music therapy program has been established by a western train, professional music therapist. 
无锡精神卫生中心精神康复科，建立于2009年，是无锡第一家拥有精神康复 项目的公立医院，自2010年开始尝试引入音乐治疗。刚开始由喜欢音乐的精神 科医生1名和2名精神科护士开展，开展方式依旧以听音乐，唱歌为主。自2013 年引入一名专业音乐治疗师介入，建立以询证为基础的音乐治疗项目。

In early stage of the development of the program, the difficulties included, 1) patients have strong psychological repel to music therapy with the reasons of a lack of knowledge about rehabilitation and music therapy experience; 2) low referral rate due to psychiatrists' lack of understanding of music therapy; 3) inappropriate therapeutic environment and equipment. In these circumstances, building rapport with patients is therapist's priority. Therapist has focused on starting the program with one ward by gathering information of patients' daily schedule. Then therapist brought a guitar, and started greeting, self-introduction and offering song choices to the patients. This informal session allow therapist to build up connection with patients, collect their music preference, emotional state, and their needs. According to the information collecting from the first attempt, therapist brought some small percussion, offering music listening for entertainment purpose, to release their anxiety. For some of the initial hospitalization, music can provide them a sense of security and familiarity. Two weeks later, almost all the patients from the psychiatric rehabilitation ward have built up a good relationship with a music therapist. They were expecting the therapist and the length of the session was expanded. In order to meet everyone's needs, a group session has established for patients to connect with each other. Families, caregivers, other therapists, and medical staff were also involved in the session, even patients from other ward were attracted by the singing. The form of accessing patients and educating by experience has increased their interests in being a part of the music therapy session. However, the aim for this kind of group can only offer emotional support. The effect was not significant for a long-term period. Therefore, therapist has divided the group according to patients' ages and functions into elderly, adults, adolescents and psychology groups. In addition, therapist has developed music and movement, interest group and open group according to patients' interesting. Individual music therapy session has been also developed.

项目建立初期困难重重，主要包括1 ) 病人由于缺之康复理念，并且之前没有 好的治疗体验，因此对音乐治疗有较强的排斥心理。2) 医生由于缺之对治疗的 认识，通常会大量的进行转介。3 ) 没有适合治疗的条件 (治疗室，设备等)。 在这样情况下，首先治疗师着手做的是重新与病人建立关系。开始时治疗师重点 选择从一个病区开始，向该病区的医护人员了解病人的作息，在病人的空闲时间 中，治疗师开始带着吉他，挨个病房去与病人打招呼，自我介绍，并让病人点 歌，每间房间待的时间并不长，这种非正式的治疗体验让治疗师很快的与病区病 人建立一定的联系，并了解到每个病人到音乐喜好，情绪状态，治疗需求，之后 治疗师根据病人的不同情况，带上不同的音乐甚至是小乐器，有些病人只进行单 纯性娱乐性音乐聆听，而有些病人会用使用音乐来安抚他们紧张焦虑的情绪，有 些病人如果是刚入院的，则会通过音乐方式为其建立安全感和熟悉感。大约2周 后，该病区的所有病人几乎都与治疗师建立了很好的关系，大家开始期待音乐治 疗师的到来，并希望唱歌时间开始增长。为了满足大家的希望，治疗师把可以走 动的病人聚集到一个大的活动室，开始进行一些团体的活动，并引导病人间彼此 
连接。人来得越来越多，不仅是病人，甚至家属，护工，其他治疗师，医护人员 都会凑进来，有时其他病区的人听到歌声也被吸引过来。这种形式让大家解除了 之前对音乐治疗得误解，并重新体会到音乐治疗的鬼丰力并提高了大家的参与兴趣 度。然而随之而来的问题又产生了，在这样人数众多的小组中，治疗活动仅能是 一些浅层，支持性层次的干预，长此下去，疗效并不明显。于是，治疗师在确定 固定参与成员中，按年龄和功能，开始划分了团体 : 老年组，中年组，青年组， 心理组，此外也按照大家的兴趣方向，增加了音乐与舞动，兴趣小组，自由加入 组等项目。当然对于独立个体中，也同时有了个体治疗。

In medical setting, gaining support from doctor is the key factor to determine the success of developing a new discipline. Good doctor can well explain the effectiveness of music therapy, decrease the patients' drop-out rate, and encourage family to support the rehabilitation in order to keep the treatment on track. For arousing doctor's awareness and having a better understanding of the music therapy process and its effectiveness. Therapist has developed music therapy assessment tool and session note template based on the American version in mental hospital, and the culture diversities. At the same time, cooperate with the engineers to develop a digital workstation for keeping and sharing the session notes and data with the psychiatrists. In addition, the system will display the condition of referral, including appropriate patients and group size, in order to ensure the professional of therapists with a reasonable caseload.

在医疗中，医生的支持对于新兴专业的生存起到了至关重要的作用。好的医 生不仅能为病人很好的解释音乐治疗的作用，并且能减少病人治疗脱落的情 况，甚至会鼓励家属支持康复治疗，从而也保证治疗的顺利进行。为了让医生 更好的了解音乐的治疗流程及疗效，治疗师按照美国精神病音乐治疗评估表为 基础建立了适合国内的音乐治疗评估量表，治疗记录模版等工具，并与医院的 工程师合作一起将所有治疗工具及记录建立成治疗师电子工作站，将治疗中的 数据与医生共享。此外治疗的转介条件，适合人员及人数限制也会在系统上会 显示出来，确保治疗师在合理的个案数量中进行专业的治疗。

It is very important to educate medical staff regarding the knowledge of music therapy in various methods, including formal presentation, informal show in terms of patients' rehabilitation results and the therapeutic experience from the medical staff, which help increase the medical team's awareness of music therapy.

当然，运用多种方式Educate医护人员关于音乐治疗的知识是非常重要的。 专业的演讲，病人的康复成果展示，医护人员的治疗体验等方式都能有效的增 强医疗人员对音乐治疗的意识。

\section{MT internship program in Wuxi Mental Health Center}

MTPW has set up the internship program with the Gaotian Music Therapy Research Center since 2014. It also owns the first music therapy internship program in medical field. There are more than 50 interns from all over the world participate in the program. Interns have to finish at least 720 hours for clinical work, and at least 10 hours on a weekly base for supervision. During internship, interns have to study music therapy theory, 
independently to conduct music therapy sessions, complete documentation and music therapy ethics. At the final stage, interns have to complete one-hour oral clinical report for evaluation. In all, the standard of internship is according to the University of Temple.

自2014年，我们同时与高天音乐治疗研究中心立了实习生合作项目，该机构 也做为第一个音乐治疗师医疗领域实习项目，至今以接待超过 50 名全世界各地 音乐治疗的学生，学生需要完成至少720个小时的临床实习时间，每周进行不少 于10小时的督导。实习过程中，不仅需要了解相关音乐治疗的理论，并要求能 够独立进行音乐治疗实践操作及文档和疗效记录，同时需要进行治疗师Ethic 的 学习，在实习最后，需要完成至少1小时的实习汇报，实习的评判的标准为美国 temple大学音乐治疗实习条件规定。

Up to the present, MTPW is one of the representative music therapies of Chinese medical field. It has established the operational standard to adapt Chinese medical system during 3 years. The MTPW team is not only provide music therapy sessions for patients with mental health problem in $\mathrm{MHCW}$, but also cooperate with several organizations including company, mainstream school, nursing home, prison, drug rehabilitation center, special school to offer music therapy services. In addition, MTPW also organized international music therapy conferences and trainings constantly.

自目前为止，无锡音乐治疗已做为中国医疗界音乐治疗的代表之一，3年中 建立了符合中国医疗体系的音乐治疗操作规范，目前团队的工作不仅在院内进 行精神疾病患者的康复工作，同时在无锡的多个机构，包括企业，学校，老人 院，监狱，戒毒所，特叫学校等建立连接，为这些领域的人群进行音乐治疗服 务。此外中心也不断承办国际级音乐治疗会议及培训班。

MHCW is the syndic unit of the Chinese Music Therapy Association, Chinese Art Therapy Association and Chinese Rehabilitation Association. MHCW is actively working to build up the bridge in-between music therapy and medical rehabilitation, with a strong willingness to promote music therapy into rehabilitation physicians' system and psychological system. This is also to help more professional music therapists gain self-identity when they step into the medical system to offer a better care service.

目前我们做为中国音乐治疗学会的理事单位，中国艺术治疗学组单位，中国 康复治疗理事单位，正积极的在音乐治疗与医疗康复领域中搭建强梁，希望将 音乐治疗纳入到康复治疗师系统，及心理治疗的大团队中，让更多的专业治疗 师获得职业自我认同，从而能更好的进入到医疗系统，为更多的患者服务。

\section{About the author}

Qian Li 李茜, Australian Registered Music Therapist (RMT), Director, Mental Health Center, Wuxi Province, China

Email: qianli_mt@hotmail.com

ORCID: 0000-0002-3740-1815

\section{Reference}

Tian, Gao (2007). Basic theory of music therapy. Beijing: World Publishing Corporation. 